\title{
EDITORIAL
}

\section{COVID-19: what the clinician should know about post-mortem findings}

\author{
Danny Jonigk ${ }^{1,2}$, Bruno Märkl $^{3}$ and Julie Helms $s^{4,5^{*}}$ (i)
}

(0) 2020 Springer-Verlag GmbH Germany, part of Springer Nature

As of September 2020, the severe acute respiratory syndrome coronavirus 2 (SARS-CoV-2) pandemic has led to over 33 million infections and 1.000 .000 deaths worldwide [1]. Compared to other coronavirus outbreaks (SARS-CoV-1, MERS-CoV), SARS-CoV-2 is characterized by a higher basic reproductive rate and an overall lower mortality [2]. However, while coronavirus disease 2019 (COVID-19) typically begins as an infection of the upper aerodigestive tract, it may progress to severe forms, with an acute respiratory distress syndrome (ARDS) and a multisystemic disease.

COVID-19 ARDS shares the common histological hallmarks with other infectious/non-infectious ARDS. Unspecific diffuse alveolar damage (DAD), as its histologic correlate, is characterized by edema, hemorrhage and intra-alveolar fibrin deposition, but in case of COVID-19 ARDS, also by a distinct angiocentric lymphocytic inflammation [3-5]. DAD is the leading pattern of lung injury and has been shown to be independent of mechanical ventilation. There is some evidence for alternative injury patterns in COVID-19 ARDS, such as acute fibrinous organizing pneumonia (AFOP). Nonetheless, COVID-19-induced DAD is by far the most frequently reported one and is also characterized by more distinct morphologic features, including vascular changes [5].

In that, the detection of SARS-CoV-2 in multiple organs (respiratory tract, heart, endothelium, digestive tract, kidneys, brain) and multisystemic clinical features, suggest that COVID-19 might be a systemic "vascular disease" (Fig. 1). The vasculature indeed appears to be

\footnotetext{
*Correspondence: Julie.helms@chru-strasbourg.fr

${ }^{4}$ Service de Médecine Intensive-Réanimation, Hôpitaux Universitaires de Strasbourg, Nouvel Hôpital Civil, 1, place de l'Hôpital, 67091 Strasbourg cedex, France

Full author information is available at the end of the article
}

more than a mere means of virus propagation. After virus respiratory tract invasion, the cytokine storm secondary to the innate and adaptive immune responses, along with a potential direct cytopathic effect of the virus, are likely to trigger an endothelial dysfunction [6, 7]. SARS-CoV-2 thus leads to three distinctive angiocentric features with: $i$. endothelial damage associated with intracellular SARS$\mathrm{CoV}-2$ virus, platelet activation, elevated $\mathrm{D}$-dimers and fibrinogen; $i$. widespread vascular thrombosis, and iii. abnormal vascular architecture (intussusceptive neoangiogenesis), suggesting microangiopathy [8] and resulting in disrupted laminar blood flow and vasoconstriction. This special form of vascularization is thought to act as an aberrant reaction to the viral aggression [4, 9]. The extensive endothelial damage seen in postmortem examinations also suggested viral inclusions being critically involved, but also endothelial inflammation with mononuclear cell infiltrate and lymphocytic endotheliitis, which may account not only for pulmonal damage but for the systemic impaired microcirculatory function in lung, kidney, liver, heart, small intestine in most severe forms of COVID-19 with subsequent organ dysfunction (supplementary figure) [7]. Deep vein thrombosis and pulmonary thromboembolism are one of the most severe consequences of this vascular disease. On the other hand, hemorrhagic colitis, an under-recognized COVID-19 complication, may occur due to microangiopathy of the intestinal vasculature [10].

Noteworthy, cardiac involvement does not involve the classic morphologic features of viral myocarditis. SARS$\mathrm{CoV}-2$ detection is rare and, therefore, a damage similar to the lungs is unlikely. Indeed, cardiac histopathological findings combine inflammatory and prothrombotic features, with rather mild epicardial inflammation and mononuclear infiltrate, with local occasional small vessel thrombi, congestive cardiomyopathy, and a few cases of focal lymphocytic myocarditis. Other findings, however,

\section{Springer}


are attributed to prior conditions, like atherosclerotic coronary artery disease, chronic ischemic cardiomyopathy, myocardial hypertrophy $[6,11,12]$.

Beside respiratory manifestations, up to $30 \%$ of the patients with COVID-19 may develop acute kidney injury. Postmortem findings mainly revealed morphological hallmarks of extensive acute tubular damage and necrosis, with marked degenerative changes and glomerulopathy appearing to be in line with other viral infections of the kidney $[6,13,14]$. Other autopsy findings included arterionephrosclerosis, extensive degenerative changes, focal segmental glomerulosclerosis and hypertensive changes in most patients (80\%) [4].

Similarly, most severe patients with COVID-19 also frequently develop moderate disturbed liver and pancreatic functions. However, both damages are nonspecific and more likely to be due to the critical illness or preexisting disease. Liver damages indeed mainly consisted of cirrhosis and steatosis, sinusoidal congestion and dilation, lobular lymphocytic infiltrates, hepatitis, necrosis, venous obstruction, thrombi and hemophagocytosis [4, 6]. Hemophagocytosis, mainly lymphophagocytosis was also identified within the lymph nodes, bone marrow, and spleen $[4,6]$.

Finally, a bundle of evidence has assessed the neurotropism and neurological injury caused by SARS$\mathrm{CoV}-2$, although the multiple pathways to access the central nervous system (CNS) in COVID-19 patients are unknown. Ultrastructural analysis autopsy findings of SARS-CoV-2 in the olfactory pathways and brainstem have shown that SARS-CoV-2 may also reach the $\mathrm{CNS}$, from the nasal mucosa to the olfactory bulb via the cribriform plate and be transported by the cerebrospinal fluid to the adjacent and distant areas of the CNS. Indeed, SARS-CoV-2 virion particles have been reported in the neurons, glia, nerve axons, and myelin sheath, and widespread tissue damage have been described by Bulfamante et al. [15]. Other authors, however, identified only weak alterations of the CNS with no or infrequent direct virus detection in the nervous parenchyma and cerebrospinal fluid $[11,16]$. Other histopathological findings in the central nervous system are similar to those of other organs and include vascular abnormalities with widespread microthrombi, ischemic necrosis, vascular edema, and dotted subarachnoid hemorrhages [4, 6]. Pooling

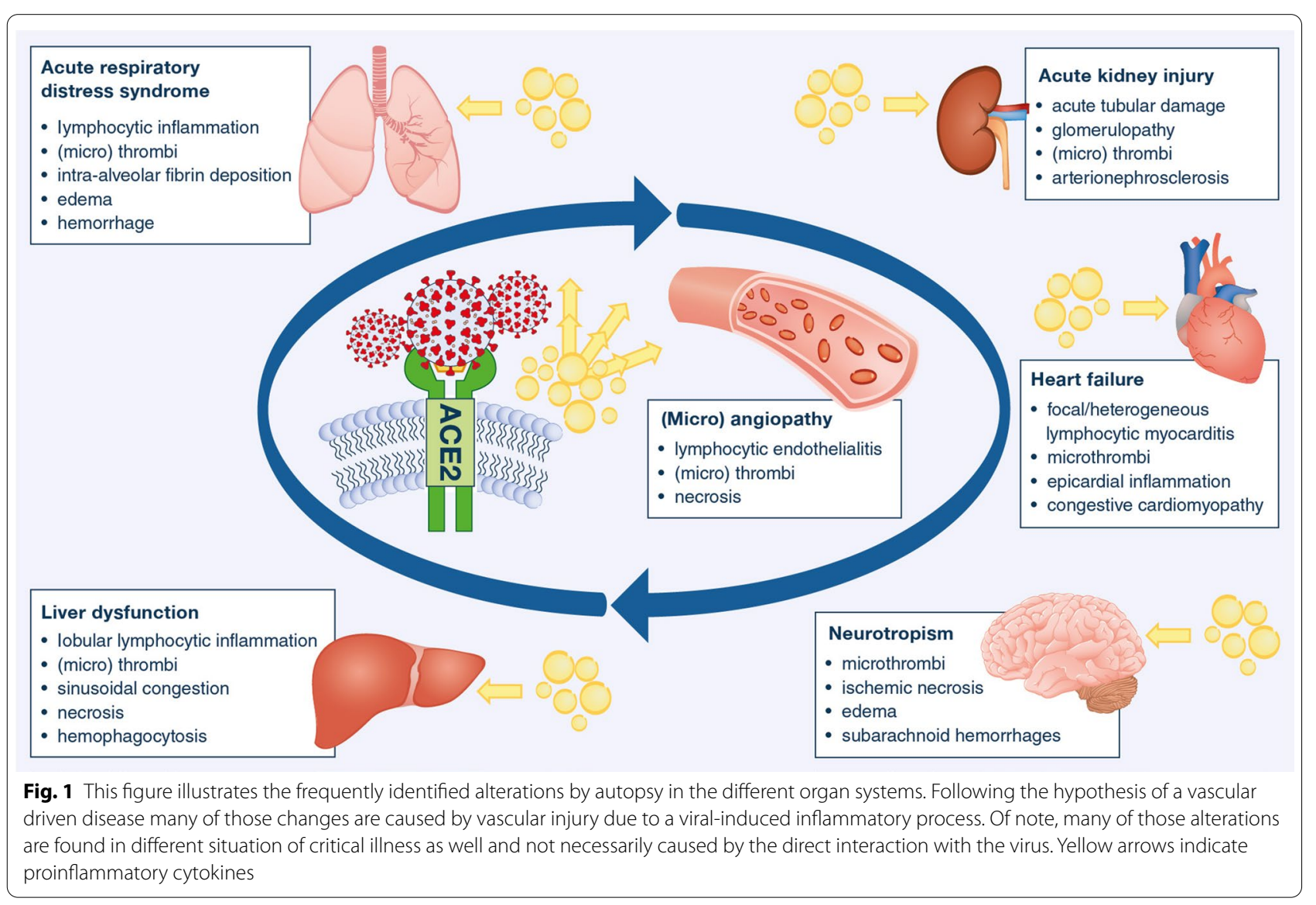


data of different studies to build larger series and minute histological work up as well as multi-omics analyses with radiological correlation will eventually lead to distinguishing between well-known alterations in other situations of critical illness and COVID-19-specific structural and functional changes.

Our understanding of how the virus spreads within patients, as well as how organs undergo molecular alterations remains very limited. Variability in post-mortem examination in the early epidemics, due to the lack of appropriate biosafety conditions and/or personal protective equipment, has led to still partial findings. However, recommendations have now been published to minimize the risk of infection transmission to the employees; to our best knowledge only one infection attributable to exposure during autopsy has been published. Although autopsy-based findings mainly provide information about late stages of the disease, it appears essential to understand the discrepancies between clinical presentation and actual organ involvement. Autopsy findings have contributed to a better comprehension of the disease and therapeutic evolution since the beginning of the epidemic. Such findings have led to an understanding of the need for prevention from thrombotic events and downregulation of the immunogenic response (supplementary table). Further advances may help personalize therapy by identification of different disease types. A strong physician family relationship is the basis for receiving autopsy consent. Careful guidance of the relatives is mandatory but also a challenging task, especially for younger physicians. However, hereby contributing to medical knowledge will help future patients and can comfort grieving relatives. More autoptic data are needed to confirm certain findings and perhaps identify relations between different strains and disease progression.

\section{Electronic supplementary material}

The online version of this article (https://doi.org/10.1007/s00134-020-06302-0) contains supplementary material, which is available to authorized users.

\begin{abstract}
Author details
${ }^{1}$ Institute of Pathology, Hannover Medical School, Hannover, Germany. ${ }^{2}$ Member of the German Center for Lung Research, Biomedical Research in Endstage and Obstructive Lung Disease Hannover (BREATH), Hannover, Germany. ${ }^{3}$ General Pathology and Molecular Diagnostics, Medical Faculty, University of Augsburg, Augsburg, Germany. ${ }^{4}$ Service de Médecine Intensive-Réanimation, Hôpitaux Universitaires de Strasbourg, Nouvel Hôpital Civil, 1, place de l'Hôpital, 67091 Strasbourg cedex, France. ${ }^{5}$ ImmunoRhumatologie Moléculaire, INSERM UMR_S1109, LabEx TRANSPLANTEX, Centre de Recherche d'Immunologie et d'Hématologie, Faculté de Médecine, Fédération de Médecine Translationnelle de Strasbourg (FMTS), Fédération Hospitalo-Universitaire (FHU) OMICARE, Université de Strasbourg (UNISTRA), Strasbourg, France.
\end{abstract}

\section{Acknowledgements}

The authors thank Maximilian Ackermann and Petra Jasker for their continued support.

\section{Author contributions}

All authors whose names appear on the submission read and approved the final manuscript.

\section{Funding}

European Research Council Consolidator Grant (XHale) (771883, to Danny Jonigk).

\section{Compliance with ethical standards}

\section{Conflicts of interest}

The authors have no conflicts of interest to declare.

\section{Publisher's Note}

Springer Nature remains neutral with regard to jurisdictional claims in published maps and institutional affiliations.

Received: 28 August 2020 Accepted: 15 October 2020 Published online: 3 November 2020

\section{References}

1. COVID-19 dashboard by the center for systems science and engineering (CSSE) at Johns Hopkins university (JHU): coronavirus ressource center. https://coronavirus.jhu.edu/map.html

2. Rockx B, Kuiken T, Herfst S, Bestebroer T, Lamers MM, Oude Munnink BB, de Meulder D, van Amerongen G, van den Brand J, Okba NMA, Schipper D, van Run P, Leijten L, Sikkema R, Verschoor E, Verstrepen B, Bogers W, Langermans J, Drosten C, Fentener van Vlissingen M, Fouchier R, de Swart R, Koopmans M, Haagmans BL (2020) Comparative pathogenesis of COVID-19, MERS, and SARS in a nonhuman primate model. Science 368:1012-1015

3. Carsana L, Sonzogni A, Nasr A, Rossi RS, Pellegrinelli A, Zerbi P, Rech R, Colombo R, Antinori S, Corbellino M, Galli M, Catena E, Tosoni A, Gianatti A, Nebuloni M (2020) Pulmonary post-mortem findings in a series of COVID-19 cases from northern Italy: a two-centre descriptive study. Lancet Infect Dis S1473-3099(20):30434-30435

4. Bradley BT, Maioli H, Johnston R, Chaudhry I, Fink SL, Xu H, Najafian B, Deutsch G, Lacy JM, Williams T, Yarid N, Marshall DA (2020) Histopathology and ultrastructural findings of fatal COVID-19 infections in Washington State: a case series. Lancet 396:320-332

5. Ackermann M, Verleden SE, Kuehnel M, Haverich A, Welte T, Laenger F, Vanstapel A, Werlein C, Stark H, Tzankov A, Li WW, Li VW, Mentzer SJ, Jonigk D (2020) Pulmonary vascular endothelialitis, thrombosis, and angiogenesis in covid-19. N Engl J Med 383:120-128

6. Remmelink M, De Mendonca R, D'Haene N, De Clercq S, Verocq C, Lebrun L, Lavis P, Racu ML, Trepant AL, Maris C, Rorive S, Goffard JC, De Witte O, Peluso L, Vincent JL, Decaestecker C, Taccone FS, Salmon I (2020) Unspecific post-mortem findings despite multiorgan viral spread in COVID-19 patients. Crit Care 24:495

7. Varga Z, Flammer AJ, Steiger $P$, Haberecker $M$, Andermatt $R$, Zinkernagel AS, Mehra MR, Schuepbach RA, Ruschitzka F, Moch H (2020) Endothelial cell infection and endotheliitis in COVID-19. Lancet 395:1417-1418

8. Goshua G, Pine AB, Meizlish ML, Chang CH, Zhang H, Bahel P, Baluha A, Bar N, Bona RD, Burns AJ, Dela Cruz CS, Dumont A, Halene S, Hwa J, Koff J, Menninger H, Neparidze N, Price C, Siner JM, Tormey C, Rinder HM, Chun HJ, Lee Al (2020) Endotheliopathy in COVID-19-associated coagulopathy: evidence from a single-centre, cross-sectional study. Lancet Haematol 7:e575-e582

9. Mentzer SJ, Konerding MA (2014) Intussusceptive angiogenesis: expansion and remodeling of microvascular networks. Angiogenesis 17:499-509

10. Chan KH, Lim SL, Damati A, Maruboyina SP, Bondili L, Abu Hanoud A, Slim J (2020) Coronavirus disease 2019 (COVID-19) and ischemic colitis: an under-recognized complication. Am J Emerg Med 27:30432-30430

11. Schaller T, Hirschbuhl K, Burkhardt K, Braun G, Trepel M, Markl B, Claus R (2020) Postmortem examination of patients with COVID-19. JAMA 323:2518-2520 
12. Wichmann D, Sperhake JP, Lutgehetmann M, Steurer S, Edler C, Heinemann A, Heinrich F, Mushumba H, Kniep I, Schroder AS, Burdelski C, de Heer G, Nierhaus A, Frings D, Pfefferle S, Becker H, Bredereke-Wiedling $\mathrm{H}$, de Weerth A, Paschen HR, Sheikhzadeh-Eggers S, Stang A, Schmiedel S, Bokemeyer C, Addo MM, Aepfelbacher M, Puschel K, Kluge S (2020) Autopsy findings and venous thromboembolism in patients with COVID19: a prospective cohort study. Ann Intern Med 173:268-277

13. Gaillard F, Ismael S, Sannier A, Tarhini H, Volpe T, Greze C, Verpont MC, Zouhry I, Rioux C, Lescure FX, Buob D, Daugas E (2020) Tubuloreticular inclusions in COVID-19-related collapsing glomerulopathy. Kidney Int 98:241

14. Golmai P, Larsen CP, DeVita MV, WahI SJ, Weins A, Rennke HG, Bijol V, Rosenstock JL (2020) Histopathologic and ultrastructural findings in postmortem kidney biopsy material in 12 patients with AKI and COVID19. J Am Soc Nephrol 31:1944-1947

15. Bulfamante G, Chiumello D, Canevini MP, Priori A, Mazzanti M, Centanni S, Felisati G (2020) First ultrastructural autoptic findings of SARS -Cov-2 in olfactory pathways and brainstem. Minerva Anestesiol 86:678-679

16. Meinhardt JRJ, Dittmayer C, Mothes R, Franz J, Laue M, Schneider J, Brünink S, Hassan O, Stenzel W, Windgassen M, Rößler L, Goebel H, Martin H, Nitsche A, Schulz-Schaeffer W, Hakroush S, Winkler M, Tampe B, Elezkurtaj S, Horst S, Oesterhelweg L, Tsokos M, Ingold Heppner B, Stadelmann C, Drosten C, Corman V, Radbruch H, Heppner F (2020) Olfactory transmucosal SARS-CoV-2 invasion as port of central nervous system entry in COVID-19 patients. bioRxiv. https://doi. org/10.1101/2020.06.04.135012v1 